九病虫研会報 $54: 18-23(2008)$

Kyushu Pl. Prot. Res. 54 ：18-23（2008）

\title{
長崎県におけるビワ産地での病害虫の 発生状況と防除の実態
}

\begin{abstract}
森田＼cjkstart昭
Occurrence and control of pests in loquat fields in Nagasaki Prefecture. Akira Morita (Omura, Nagasaki 856-0021, Japan)

長崎県のビワ産地における病害虫の発生状況と防除実施について1981年〜1988年の 8 年間調査 した。その結果, 枝葉の病害では灰斑病が $50.9 \%$, 虫害ではナシマルカイガラムシが $37.6 \%$ と最 も高く, 果害の病害虫ではたてぼや病が5. $1 \%$ と最も高った。ビワの栽培管理の中では病害虫防 除の実施率が $81.8 \%$ と最も低く，無防除園が約 $20 \%$ あた。長崎県のビワ栽培現場での病害虫に 対する年間防除回数は平均 2.5 回, 年間農薬使用数は平均 3.9 薬剤で樹勢を低下させるがんしゅ病, ナシマルカイガラムシおよび果実品質を低下させるたてぼや病対象の防除回数が多かった。がん しゅ病は病斑部削り取り・薬剂塗布後毎年銅水和剂を散布, 白紋羽病は根部掘り上げ・薬剂処理 後に毎年根部土㙴へ薬剤を灌注処理，クワカミキリは枝幹部潜入の幼虫を針金で刺殺後に毎年産 卵枝を除去するなど 1 回きりの防除でなく毎年防除作業を継続することで高い効果が得られた。 各種の防除指導を採用した園は健全果率および大果率が高かった。
\end{abstract}

Key words : loquat, control technique, development

緒 言

ビワは果実生産に直接被害を与える病害虫が少ないこ とから, 産地での病害虫防除の実施率は低いのが現状で ある。その結果, 長崎県のビワ樹園での発生率はがん しゅ病が $82 \%$, 灰斑病が96\%, 白紋羽病が $24 \%$, ナシヒ メシンクイが $76 \%$ あ゙あり, 他の果樹では例をみないよう な高発生園率を示している（森田ら，1979）。

そこで, 長崎県ビワ産地の病害虫の発生と防除の実態 を1981年～1988年に調査することによって，防除が病害 虫発生と果実生産に及ぼしている影響を明らかにし，防 除の必要性を実証した。さらに, ビワ難防除病害虫（が んしゅ病, 白紋羽病, クワカミキリ）の効果的な防除法 についても検討したので，その概要を報告する。

本研究を行うに当たり, 終始御教示と論文の校閲を 賜った佐賀大学名誉教授野中福次博士に厚く御礼申し上 げる。

\section{材料および方法}

\section{1．調査園および樹の選定}

調査場所㧍よび調査園数は, 長崎市野母:崎地区 5 園, 三和地区 5 園, 茂木地区 5 園, 東長崎地区 4 園㧍よび南
島原市 3 園の合計 22 園を選定した。その 22 園を1981年〜 1988年まで毎年同一園について調査した。供試樹は各調 査園ごとに第 1 回調査時（1981年）に 1 園に付き，10年 生茂木種10樹を選び，同一樹を1988年まで 8 年間毎年調 査した。

\section{2. 調查方法および調查時期}

1 ) 病害虫の発生状況調査 : 白紋羽病は発病樹率を, クワカミキリは 2 年生枝の虫粪確認樹率を, ナシマルカ イガラムシは 1 樹当たり 2 年生枝 10 枝の寄生枝率を, ナ シヒメシンクイは 1 樹当たり 2 年生枝 10 枝のがんしゅ病 病斑に観察される虫䨢確認枝率を，がんしゅ病は 1 樹当 たり 1 年生枝 10 枝の発病枝率を, 灰斑病, アブラムシ類 およびその他の病害虫は 1 樹当たり 1 年生枝 10 枝の全着 葉（約120枚）について発生葉率を調べた。果実の病害 虫調査は 1 樹当たり 5 果房（1 果房 3 果着生）15果を調 査し, 発生果率で示した。

2 ）ビワ栽培管理の実施状況調査 : 栽培管理作業とし てのせん定, 芽かき, 摘蕾・摘房, 摘果・袋掛け, 施肥 および除草は毎年収穫時に前年の収穫時から当年の収穫 直前までの実施の有無を聞き取り調査した。防除実績に ついては, 同様に前年の収穫時から当年の収穫直前まで の防除の有無, 使用薬剤名, 薬剤散布回数揖よび防除時 
期を聞き取り調査した。また, 調査 1 か月後に個々の調 查園および全調査園の平均病害虫発生状況の結果を個々 の調査対象農家に提示し，防除の改善点を各農家に指示 した。この改善点の採用による病害虫防除効果確認のた めに，各農家が採用した対象病害虫の種類および発生状 況を指導 1 年後の収穫時に調査した。この改善点の採用 率を(1)指導通り防除, (2)一部指導採用防除, (3)指導無採 用防除（指導を全て採用せず独自に防除），(4)無防除に， さらに1898年・1924年頃から栽培が始められている旧産 地（長崎市茂木地区, 東長崎地区）と1964年・1966年 · 1971年に開園した新産地（長崎市三和地区, 野母崎地区, 南島原市）に分けて各園数を調査した。また, 各病害虫 と防除指導項目毎に指導園数と指導採用園数を調べ, 採 用園率で示した。

3）ビワ難防除病害虫（クワカミキリ, ビワ白紋羽病, ビワがんしゅ病枝幹部病斑）の防除法：クワカミキリに 対して効果のある有機燐剂系農薬は薬害がビワ樹に発生 するため使用できない。そこで，長崎県の栽培現場では クワカミキリは虫糞発生部位に針金を差し込み, 樹内の 幼虫を刺殺する方法で防除している。この方法の効果を より高めるために幼虫刺殺後産卵枝除去を 5 年間行い, その効果を検討した。その方法は, 幼虫刺殺後 5 年間 (1984～1988年)，毎年産卵枝除去区と無除去区各区 2 園・100枝の 2 年生側枝（径10 20mm） の虫粪確認枝 数を調査し, 5 年間の累積虫粪確認枝数で示した。

ビワ栽培現場での白紋羽病の防除は, 樹体を堀り上げ て病根部を除去し，チオファネートメチル水和剤500倍 液（大野ら，1974）を根部および土壤に灌注処理するこ とによる防除を行っている。しかし，この方法は再発す ることが多いことから, この防除効果を持続させるため に次の試験を行った。前記防除後，更に 5 年間（1984〜 1988年), 毎年収穫後にビワ根辺土壌へチオファネート メチル水和剂 500 倍液を 1 樹当たり $50 l$ 灌注した 4 樹につ
いて，5年後の再発病樹数を調査した。対照に無灌注樹 4 樹についても再発病樹数を調査した。

現場でのがんしゅ病枝幹部病斑の防除は罹病枝をせん 除するか, 病斑を削り取り後にカルタップ水溶剂 $5 \%$ 加 用ペースト状ストレプトマイシン（長崎県防除基準, 1985，2008年現在は登録失効）を塗布する外科的治療法 が行われているが, 再発病することが多い。そこで, 再 発病を防止するために, この処理後, 毎年防除適期の萌 芽期 ( 2 月下旬), 収穫後 ( 6 月上旬), 芽かき後（ 7 月 中旬）とせん定後（9月上旬）の 4 回，銅水和剂 1,000 倍とカルタップ水溶剤 1,000 倍の混合液を 5 年間（1984 〜1988年）散布した 4 園・40樹（71病斑）と無散布樹 4 園・40樹 (74病斑) の再発病斑数を調査し，その効果を 検討した。

4 ）防除指導採用の有無と病害虫の発生および果実肥 大との関係：農家の指導採用による防除効果を明らかに するために，指導採用防除園と無採用防除園の病害虫の 発生状況を各 3 園, 1園当たり 10 樹について前述した供 試176園の病害虫の発生状況調査法と同様に 8 年間調へ た。また, 各園150果, 1 区 3 園計450果の健全果率を調 査し, 健全果の果実階級 $2 \mathrm{~L}$ (55g 以上/1果), L (40g 55g/ 1 果), M (30g 40g/ 1 果), S ( $25 \mathrm{~g} \sim$ $30 \mathrm{~g} / 1$ 果), $2 \mathrm{~S}$ ( $25 \mathrm{~g}$ 以下/ 1 果) の比率調査を, いず れも最終年の1988年の収穫時に行った。

\section{結果および考察}

\section{1. 調査ビワ園での病害虫の発生状況の実態}

ビワ枝葉の病害虫発生率は第 1 表に示す通り, 最も高 いのは病害では死斑病で50.9\%, 害虫ではナシマルカイ ガラムシで $37.6 \%$ あ゙あた。果実の病害虫発生率は第 2 表に示しているように，枝葉に比べ全体的に低く，たて ぼや病が $5.1 \%$ で最も高かった。果実での発生率が低い のは，ビワは有袋栽培が基本であることから，袋掛けが

第 1 表 ビワ枝葉における調査園（176園）での病害虫平均発生率（1981～1988年）（\%）

\begin{tabular}{|c|c|c|c|c|c|c|c|c|}
\hline & 病 & 害 & & & 害 & & & \\
\hline がんしゅ病 & 灰斑病 & 白紋羽病 & その他 & $\begin{array}{l}\text { ナシヒメ } \\
\text { シンクイ }\end{array}$ & $\begin{array}{c}\text { ナシマルカイ } \\
\text { ガラムシ }\end{array}$ & $\begin{array}{l}\text { クワカ } \\
\text { ミキリ }\end{array}$ & $\begin{array}{l}\text { アブラ } \\
\text { ムシ類 }\end{array}$ & その他 \\
\hline 16.0 & 50.9 & 3.3 & 7.4 & 7.2 & 37.6 & 10.0 & 3.3 & 3.8 \\
\hline
\end{tabular}

第 2 表 ビワ果実における調査園（176園）での病害虫と障害果の平均発生率（1981～1988年）（\%）

\begin{tabular}{|c|c|c|c|c|c|c|c|c|}
\hline & & 病 & 害 & & & & 害 & \\
\hline がんしゅ病 & 灰斑病 & 炭疽病 & 疫病 & たてぼや病 & その他 & $\begin{array}{l}\text { ナシヒメ } \\
\text { シンクイ }\end{array}$ & $\begin{array}{c}\text { モノゴマ } \\
\text { ダラノメイガ }\end{array}$ & その他 \\
\hline 2.3 & 0.4 & 1.5 & 0.1 & 5.1 & 0.1 & 0.6 & 1.0 & 1.4 \\
\hline
\end{tabular}


物理的に病害虫の発生を防止しているものと思われる。

\section{2. ビワ園の栽培管理と病害虫防除の実施状況}

ビワ園の管理状況は第 3 表に示す通りである。芽かき, 摘果・袋掛け, 施肥, 除草の作業は, 全農家が $100 \%$ 実 施し, せん定は $93.2 \%$, 摘蕾・摘房は91.3\%であったが, 病害虫防除は $81.8 \%$ の実施率であった。

第 3 表 長崎県ビワ栽培園（176園）におけるビワの 管理作業の実施状況（1981～1988年）

\begin{tabular}{|c|c|c|c|c|c|c|c|c|c|}
\hline \multirow{2}{*}{ 調査項目 } & \multicolumn{3}{|r|}{ 作 } & 業 & & 項 & 目 & \\
\hline & 防除 & 摘房 & 摘蕾 & せん定 & 芽かき & 摘果 & 袋掛け & 除草 & 施肥 \\
\hline 実施園数 & 144 & 161 & 176 & 164 & 176 & 176 & 176 & 176 & 176 \\
\hline 実施率 (\%) & 81.8 & 91.3 & 100 & 93.2 & 100 & 100 & 100 & 100 & 100 \\
\hline
\end{tabular}

このように，管理作業の中で病害虫防除の実施率は低 かった。このことは無防除園が約20\%あるということで あり，これは他の果樹では考えられないと思われる。こ れが, 現地ビワ園の病害虫発生密度を高めている原因と 思われる。

\section{3. 年間防除回数と農薬使用数}

22 園・延べ 176 園についての 8 年間の年間防除回数は 第 4 表に示すように, 平均 2.5 回で, 3 回防除が最も多 く39園, 次いで無防除と 2 回防除の32園であった。年間 延べ農薬使用数は第 5 表に示すように 4 が32園と最も多 く, 平均3. 9, 最多 $12 て ゙ ~ 2$ 園あった。長崎県の基準技術 （長崎県農林業基準技術，1972年・1994年）によると， 年間基準防除回数は 7 回, 年間基準延べ農薬使用数は 8 となっており, 長崎県の生産現場では年間平均防除回数, 年間平均延べ農薬使用数ともに県の基準より少ないこと が明らかとなった。

第 4 表＼cjkstart長崎県のビワ園（176園）における年間防除 回数とその園数（1981～1988年）

\begin{tabular}{lccccccccc}
\hline \multirow{2}{*}{ 調查項目 } & \multicolumn{10}{c}{ 防除回数 } \\
\cline { 2 - 10 } & 0 & 1 & 2 & 3 & 4 & 5 & 6 & 7 & 平均 \\
\hline 園数(園) & 32 & 24 & 32 & 39 & 23 & 20 & 5 & 1 & 2.5 \\
比率(\%) & 18.2 & 13.6 & 18.2 & 22.5 & 13.1 & 11.4 & 3.4 & 0.6 & \\
\hline
\end{tabular}

第 5 表 長崎県におけるビワ園での年間延べ使用農 薬数と園数（1981～1988年）

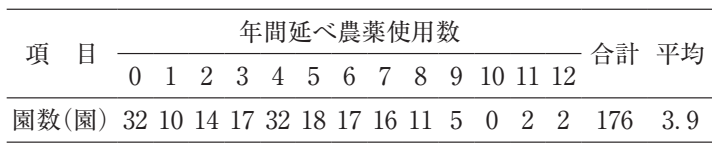

\section{4. 各病害虫別の防除回数と発生率}

各病害虫の年間防除回数は第 6 表に示すように, いず れの病害虫も 1 回散布が最も多く, がんしゅ病が年平均 1.8 回で, 実施率は全調查園の $94.9 \%$ と最も高く, 次い でナシヒメシンクイの年平均 1.6 回で, 実施率 $86.1 \%$, ナシマルカイガラムシの年平均 0.7 回で, 実施率 $61.9 \%$, の順であった。

このように，がんしゅ病の防除が最も多いが，本病の 薬剤散布による防除回数は年 $4 \sim 5$ 回（森田ら, 1981） （長崎県防除基準，1985）となっていることから，年平 均1.8回で十分な防除ができているかどうか問題である。 病害虫別使用農薬と 22 園に対する 8 年間の累積使用回 数は第 7 表に示すように, がんしゅ病に対して259回で 最も多く, その使用農薬は銅水和剤と石灰ボルドーで あった。次いでナシヒメシンクイの 230 回で, その使用 農薬はカルタップ水溶剤であった。ナシマルカイガラム シは109回であったが, 灰斑病, 炭疽病（果実），たてぼ や病に対しては50回以下であった。

がんしゅ病とナシヒメシンクイは防除時期が大体一致 しているため同時防除を行うことから, 同程度の防除回 数になると思われる。また, がんしゅ病は樹勢を低下さ せ, 白紋羽病の発生（森田ら，1979）や, 収量低下を招 くことから（森田, 1991）, 防除回数が多いものと思わ れる。灰斑病は激発すると落葉の原因となる（禧久・河 野, 1974）が, 樹体への影響が低いために（森田ら, 1979）防除回数が少ない。しかし, 本病は果実にも発生 し, 果実腐敗の原因菌であることから（森田, 1995 ；小 西, 1937), 葉病斑密度を低下させ, 果実への感染防止 のためにも防除回数を増す必要がある。ナシマルカイガ

第 6 表 長崎県ビワ園における薬剤防除実施144園での病害虫別年間防除回数

\begin{tabular}{|c|c|c|c|c|c|c|c|c|}
\hline \multirow{2}{*}{ 防除対象病害虫名 } & \multicolumn{5}{|c|}{ 各散布回数の園数（園） } & \multirow{2}{*}{$\begin{array}{l}\text { 実施園数 } \\
\text { (園) }\end{array}$} & \multirow{2}{*}{$\begin{array}{c}\text { 実施率 } \\
(\%)\end{array}$} & \multirow{2}{*}{$\begin{array}{l}\text { 実施園の平均散 } \\
\text { 布回数 (回) }\end{array}$} \\
\hline & 0 & 1 & 2 & 3 & 4 & & & \\
\hline がんしゅ病（薬剤散布） & 8 & 57 & 41 & 32 & 6 & 136 & 94.9 & 1.8 \\
\hline 灰斑病 & 120 & 23 & 1 & 0 & 0 & 24 & 16.7 & 0.2 \\
\hline 果実腐敗病害 & 121 & 23 & 0 & 0 & 0 & 23 & 16.0 & 0.2 \\
\hline たてぼや病 & 107 & 30 & 7 & 0 & 0 & 37 & 25.7 & 0.3 \\
\hline ナシヒメシンクイ & 20 & 57 & 36 & 23 & 8 & 124 & 86.1 & 1.6 \\
\hline ナシマルカイガラムシ & 55 & 71 & 16 & 2 & 0 & 89 & 61.9 & 0.7 \\
\hline
\end{tabular}


第 7 表 ビワ病害虫別の8年間における使用農薬名と延べ使用回数

\begin{tabular}{|c|c|c|}
\hline 防除対象病害虫名 & 使用農薬名と延べ使用回数 & 合計 \\
\hline がんしゅ病 & 銅水和剂97回, 石灰ボルドー 162回 & 259 \\
\hline 灰斑病 & チオファネートメチル水和剤23回, ベノミル 水和剤2回 & 25 \\
\hline 炭疽病（果実） & チオファネートメチル水和剤 22 回, ベノミル水和剤 1 回 & 23 \\
\hline たてぼや病 & チオファネートメチル水和剤44回 & 44 \\
\hline ナシヒメシンクイ & カルタップ水溶剤230回 & 230 \\
\hline ナシマルカイガラムシ & マシン95油乳剤64回, P A P 乳剤45回 & 109 \\
\hline
\end{tabular}

ラムシは激発すると樹勢を低下させ，がんしゅ病の発病 を助長させる（森田ら，1979）ことから防除回数が多い。

\section{5 ．各園の病害虫の防除への指導と病害虫発生状況}

第 8 表に示すように，指導通りの防除を実施した園は 41 園・23. 3\%, 一部指導採用防除は68園・38.6\%で，新 産地に多かった。一方, 無防除は32園・18.2\%, 指導無 採用防除は35園・19.9\%で，旧産地に多かった。病害虫

第 8 表 指導に準拠して防除したビワ園数と新旧産 地別園数

\begin{tabular}{lrccc}
\hline \multicolumn{1}{c}{ 項目 } & $\begin{array}{c}\text { 園数 } \\
\text { (園) }\end{array}$ & $\begin{array}{c}\text { 割合 } \\
(\%)\end{array}$ & $\begin{array}{c}\text { 旧産地園数 } \\
(\text { (園) }\end{array}$ & $\begin{array}{c}\text { 新产地園数 } \\
(\text { 園) }\end{array}$ \\
\hline 指導通りの防除 & 41 & 23.3 & 4 & 37 \\
一部指導採用防除 & 68 & 38.6 & 10 & 58 \\
指導無採用防除 & 35 & 19.9 & 21 & 14 \\
無防除 & 32 & 18.2 & 32 & 0 \\
\hline \multicolumn{1}{c}{ 合計 } & 176 & & 72 & 104 \\
\hline
\end{tabular}

別の指導採用率は第 9 表に示すように，樹勢低下に関与 するがんしゅ病 (薬剤散布)，ナシマルカイガラムシお よび果実品質に影響するたてぼや病などが高かった。し かし, がんしゅ病の病斑削り取り後薬剤塗布, 白紋羽病 の堀上後薬剂処理およびクワカミキリの針金による幼虫 刺殺などは処理に多大な労力を要するため採用率が低 かった。しかし, がんしゅ病病斑削り取り・薬剤塗布を 行った園での樹体への薬剤散布, 白紋羽病の堀上・薬剤 処理を行った園での根辺土壤への薬剤灌注およびクワカ ミキリ幼虫を針金刺殺処理を行った園での産卵枝切除な どの実施率は高かった。また，第10表に示すように，が んしゅ病は病斑削り取り・薬郕塗布を行った後に樹体へ の薬剂散布を行わなかった園での 5 年後の再発病斑数が 71 病斑中37病斑であったのに対して, 薬剤散布を 5 年間 継続した園では再発病斑数が74病斑中 2 病斑のみとなり 激減した。白紋羽病は根部堀上薬剤処理後, 薬剂灌注を

第 9 表 農家が防除指導を採用した対象病害虫防除のための作業名と採用園率

\begin{tabular}{|c|c|c|c|}
\hline 指導病害虫名と指導項目 & 指導園数（園） & 採用園数（園） & 採用園率（\%） \\
\hline \multicolumn{4}{|l|}{ がんしゅ病 } \\
\hline 薬剤散布 & 73 & 41 & 56.2 \\
\hline 病斑削り取り薬骫塗布 & 92 & 18 & 19.6 \\
\hline 病斑削り取り薬剤塗布後薬剤散布 ${ }^{a)}$ & 18 & 14 & 77.8 \\
\hline \multicolumn{4}{|l|}{ 白紋羽病 } \\
\hline 根部堀上薬骫処理 & 74 & 11 & 14.9 \\
\hline 根部堀上薬剤処理後薬剤灌注 b) & 11 & 5 & 45.5 \\
\hline 果実腐敗病害薬荗散布 & 31 & 14 & 45.2 \\
\hline たてぼや病薬剤散布 & 22 & 16 & 72.7 \\
\hline 灰斑病薬剤散布 & 12 & 2 & 16.6 \\
\hline ナシマルカイガラムシ薬剤散布 & 89 & 46 & 51.7 \\
\hline \multicolumn{4}{|l|}{ 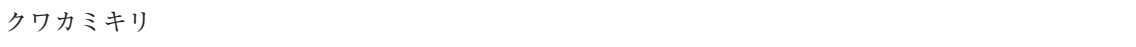 } \\
\hline 枝幹部食入幼虫刺殺 & 36 & 9 & 25.0 \\
\hline 枝幹部食入幼虫刺殺後産卵枝除去 ${ }^{c}$ ) & 9 & 6 & 66.7 \\
\hline ナシヒメシンクイ薬剤散布 & 71 & 39 & 54.0 \\
\hline
\end{tabular}
a) 病斑削り取り薬剤塗布の指導を採用実施した園のみ指導.
b）根部堀上薬剤処理の指導を採用実施した園のみ指導.
c）枝幹部食入幼虫刺殺処理の指導を採用実施した園のみ指導. 
第10表 第1処理後5年間継続して第2処理を実施したビワ園と無実施園におけるの各病害虫の発生状況

\begin{tabular}{|c|c|c|c|c|c|c|}
\hline \multirow{2}{*}{$\begin{array}{l}\begin{array}{l}\text { 病害虫名 } \\
\text { 第 } 1 \text { 処理法 }\end{array} \\
\text { 第 } 2 \text { 処理法 }\end{array}$} & \multicolumn{2}{|c|}{$\begin{array}{c}\text { がんしゅ病 } \\
\text { 病斑削り取り薬骫塗布 }\end{array}$} & \multicolumn{2}{|c|}{$\begin{array}{c}\text { 白紋羽病 } \\
\text { 根部堀上薬剂処理 }\end{array}$} & \multicolumn{2}{|c|}{$\begin{array}{c}\text { クワカミキリ } \\
\text { 食入枝幹幼虫刺殺 }\end{array}$} \\
\hline & $\begin{array}{l}\text { 薬剤無散布 } \\
\text { (枝病斑数) }\end{array}$ & $\begin{array}{l}\text { 薬剤散布 } \\
\text { (枝病斑数) }\end{array}$ & $\begin{array}{l}\text { 薬郕無灌注 } \\
\text { (樹数) }\end{array}$ & $\begin{array}{l}\text { 薬剤灌注 } \\
\text { (樹数) }\end{array}$ & $\begin{array}{c}\text { 产卵枝無除去 } \\
\text { (枝数) }\end{array}$ & $\begin{array}{l}\text { 产卵枝除去 } \\
\text { (枝数) }\end{array}$ \\
\hline 調査個体数 & 71 & 74 & 4 & 4 & 500 & 500 \\
\hline 再発個体数 & 37 & 2 & 4 & 0 & 216 & 4 \\
\hline 再発生率（\%） & 49.3 & 2.7 & 100 & 0.0 & 43.2 & 0.8 \\
\hline
\end{tabular}

行わなかった区では， 5 年後には 4 樹全てが再発病した のに対して， 5 年間根辺土壤へ薬郕灌注を行った区は全 く再発病しなかった。クワカミキリは産卵枝の除去を行 わなかった区では 5 年間に延べ 216 枝に虫糞が確認され たが，産卵枝除去区ではわずか 4 枝であった。このよう に，いずれの病害虫についても処理後のこれらの継続的 な防除管理作業は顕著な効果が認められた。多大な労力 を注いで行ったがんしゅ病の病斑削り取り作業, 白紋羽 病の堀上げ作業およびクワカミキリの針金による幼虫刺 殺作業を行った後の再発生を防止するためにも第10表に 示す継続的な防除作業の重要性が証明された。

\section{6. 指導に準拠した防除指導採用の有無園の病害虫発 生状況と果実生産}

第11表に示すように，がんしゅ病，ナシマルカイガラ ムシ, クワカミキリの発生率は指導採用園が無採用園よ り低く, fisher 検定でも $5 \%$ で有意差が認められた。灰 斑病, 白紋羽病, ナシヒメシンクイの発生率は指導採用 園が無採用園より低い傾向を示したが，fisher 検定では 5 \%で有意差がなかった。第 12 表に示すように，健全果 率は指導採用園が無採用園より高く fisher 検定でも有意 差 $\left(\mathrm{P}=1.63 \times 10^{-5}\right)$ が認められた。また，商品価值の 高い $2 \mathrm{~L}$ と L 級果率も指導採用園が，無採用園に比べて

第11表＼cjkstart指導に準拠して防除したビワ園と無採用園のビワ枝葉根における病害虫発生率（1981 ～1988年)

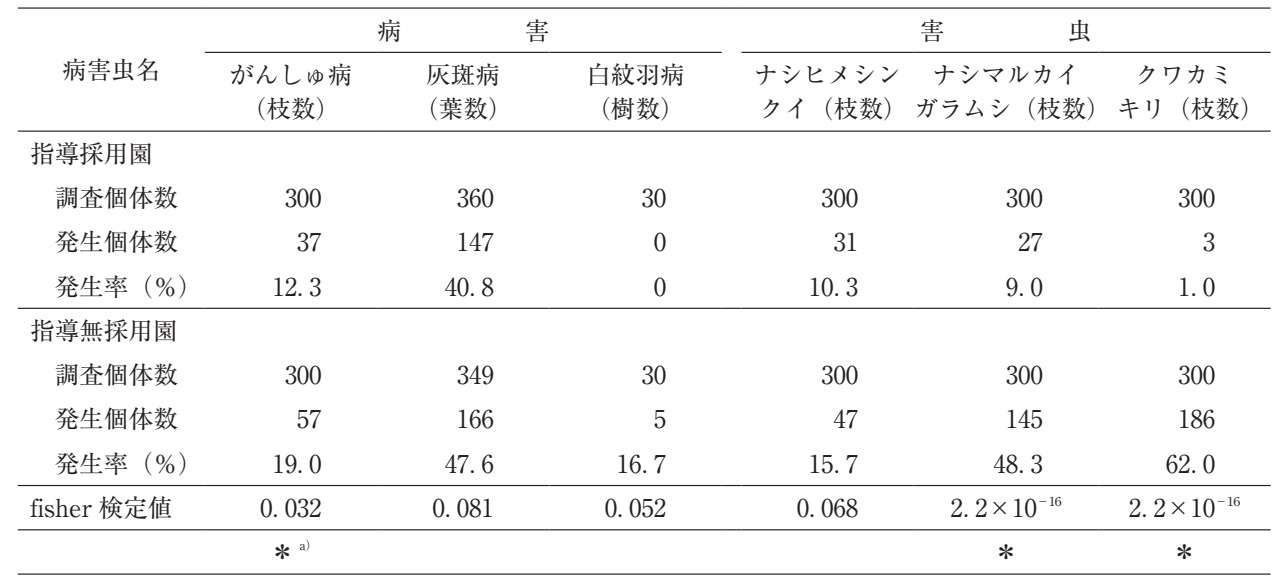

a）*は fisher 検定で有意差（5％）が認められたことを示す.

第12表＼cjkstart指導に準拠して防除したビワ園と無採用園の 健全果率および果実階級

\begin{tabular}{rrrrrr}
\hline \multirow{2}{*}{ 調查項目 } & \multirow{2}{*}{ 調查果 } & \multirow{2}{*}{ 健全果 } & \multicolumn{2}{c}{ 果実階級 } \\
\cline { 5 - 6 } & & & & $\mathrm{L}, 2 \mathrm{~L}$ & $\mathrm{M}, \mathrm{S}, 2 \mathrm{~S}$ \\
\hline 指導採用園 & 果数 (個) & 450 & 370 & 196 & 174 \\
& 率 (\%) & & 82.2 & 53.0 & 47.0 \\
指導無採用園 & 果数 (個) & 450 & 314 & 108 & 206 \\
& 率 (\%) & & 69.9 & 34.4 & 65.6 \\
\hline
\end{tabular}

高く, fisher 検定でも有意差 $\left(\mathrm{P}=1.12 \times 10^{-6}\right)$ が認め られた。現在の長崎県のビワの平均単収は 10 アール当た り0.8トンであるが, 10アール当たり1.5〜1.7トンの収 量が可能という試験結果もある（松浦ら，1999）ことか ら，適正防除を行えば，病害虫の発生を防止し，大果生 産による増収・高品質果実生産が可能という結果が得ら れた。 


\section{引用文 献}

禧久 保・河野通昭 (1974) ビワ灰斑病に関する研究 (第 1 報) 発生生態について。 九病虫研会報 $20 ： 105$ 107.

小西全太郎（1937）市場に於いてビワ果の腐敗に起因す るPestalozzia 属菌に就いて。植物病害研究 3 ：138146.

松浦 正 ·高見寿隆・今村俊清（1999）施設ビワの収量 構成要因の解明. 九農研 $61: 244$.

森田 昭 (1991) ビワ植え付け時のがんしゅ病菌接種が その後の樹体生育ならびに果実生産性に及ぼす影響.

日植病報57：629-633.

森田 昭（1995）ビワ果実腐敗病害の発生生態と防除.
長崎果樹試研報 $2 ： 41-47$.

森田 昭 - 池永和夫 · 道添英昭 ·高崎満次 (1979) ビワ がんしゅ病とビワに発生する他の病害虫との関係. 九 病虫研会報25：56-58.

森田 昭・岩佐忠行・西野敏勝 (1981) ビワがんしゅ病 防除時期の検討. 九病虫研会報 $27: 68-70$.

長崎県農林部（1972）長崎県農林業基準技術. pp. 316 .

長崎県農林部（1994）長崎県農林業基準技術. pp. 300 .

長崎県農林部（1985）長崎県病害虫防除基準・雑草防除 基準. pp. 446 .

大野鎮人・平野露治・森田 昭 (1974) ビワ白紋羽病防 除薬剂の検討. 九病虫研会報20：112-114.

(2008年 4 月 16 日受領； 8 月 1 日受理) 